\section{Examination of Nephrotoxicity in Survivors of Childhood Cancer and Comparison of Methods for Estimating Glomerular Filtration Rate}

\author{
Çocukluk Çağı Kanser Yaşayanlarında \\ Nefrotoksisitenin incelenmesi ve Glomerüler \\ Filtrasyon Hızı Yöntemlerinin Karşılaş̧ırılması
} Arzu Yazal Erdem ๑
Suna Emir ๑
Nilgün Çakar ๑
Hacı Ahmet Demir ๑
Derya Özyörük ๑

\section{ABSTRACT}

Objective: Increased survival rates in childhood cancers have led the researchers to focus on long-term side effects and possible risk factors for late nephrotoxicity related to the treatment regimens applied. Our aim is to evaluate drug-induced nephrotoxicity in survivors of childhood cancer and to investigate the compatibility of creatinine clearance with the estimated glomerular filtration rate.

Methods: The presence of glomerular and tubular dysfunction has been screened among 59 childhood cancer survivors who had completed their treatment regimens with cisplatin, carboplatin, ifosfamide, and lor high dose methotrexate.

Results: The mean age of patients was $10.7 \pm 5.5$ years (2.5-23), and mean follow-up time was $2.6 \pm 2.1$ years (0.5-8). Renal dysfunction was detected in $65 \%$ of the patients. The most prevalent manifestation of renal dysfunction was decreased glomerular filtration rate (n:19, 32.2\%), and increased urinary 62-microglobulin excretion ( $n: 12,20.4 \%)$, followed by microalbuminuria ( $n: 6,10.1 \%)$. Survivors treated with combined chemotherapy regimens (cisplatin, carboplatin, ifosfamide) had significantly lower tubular reabsorption of phosphate than those treated with high dose of methotrexate. The glomerular filtration rate analysis was performed using different methods, and a moderate correlation ( $r=0.563, p=0.00$ ) was found between estimated glomerular filtration rates calculated according to cystatin-C-based equations and Schwartz formula.

Conclusion: Childhood cancer survivors demonstrated a high frequency of renal complications in the current study. We have shown that the calculation of the estimated glomerular filtration rate using the Schwartz formula or cystatin-C-based equations is compatible with the creatinine clearance in this specific patient group. In survivors of childhood cancer who cannot perform 24-hour urine collection, determination of estimated glomerular filtration rate is a more practical approach.

Keywords: Childhood cancer survivor, glomerular filtration rate, renal function, nephrotoxicity

öz

Amaç: Çocukluk çağı kanserlerinde artan sağkalım oranları, uzun süreli tedaviye bağlı yan etkilere ve geç nefrotoksisite için olası risk faktörlerine odaklanmaya yol açmıştır. Amacımız kanser tedavisi alıp iyileşen çocuklarda nefrotoksisiteyi belirlemek ve glomerül filtrasyon hızının hesaplanmasında tahmini glomeruler filtrasyon hızı ile kreatinin klirensinin birbiri ile uyumunu araştırmaktır.

Yöntem: Sisplatin, karboplatin, ifosfamid ve/veya yüksek doz metotreksat ile kanser tedavileri tamamlanmış 59 çocuğun glomerüler ve tübüler disfonksiyonları değerlendirildi.

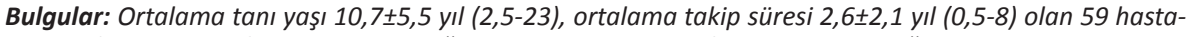
nın \%65'inde böbrek fonksiyon bozukluğu tespit edildi. Böbrek fonksiyon bozukluğunun en yaygın bulgusu azalmış glomeruler filtrasyon hızı (n:19, \%32,2), artmış üriner 62-mikroglobulin atıımı (n:12, \%20,4), ardından mikroalbuminuri $(n: 6, \% 10,1)$ idi. Kombine kemoterapi ile tedavi edilenlerde, yüksek doz metotreksat ile tedavi edilenlere göre istatistiksel anlamlı düşük tubüler fosfor reabsorbsiyonu saptandı. Serum sistatin-C ve Schwarz formülü ile hesaplanan tahmini glomeruler filtrasyon hızının birbiri ile tutarlı olduğu $(r=0,563, p=0,00)$ bulundu.

Sonuç: Çocukluk çağında kanser tedavisi alıp iyileşenlerde yüksek oranda böbrek komplikasyonlarının geliştiği gösterilmiştir. Çocukluk çağı kanser yaşayanlarında, Schwartz formülü veya sistatin-C ile tahmini glomerüler filtrasyon hızının hesaplanmasının kreatinin klirensiyle uyumlu olduğunu gösterdik. 24 saatlik idrar toplayamayan çocuklarda tahmini glomeruler filtrasyon hızı hesaplaması pratik bir yaklaşımdır.

Anahtar kelimeler: Çocukluk çağı kanser, glomeruler filtrasyon hızı, renal fonksiyon, nefrotoksisite
Received: 27.10 .2020

Accepted: 16.02 .2021

Published Online: 03.08.2021

Cite as: Yazal Erdem A, Emir S, Cakar N, Demir HA, Özyörük D. Examination of nephrotoxicity in survivors of childhood cancer and comparison of methods for estimating glomerular filtration rate. İzmir Dr. Behçet Uz Çocuk Hast. Dergisi. 2021;11(2):139-46.

Arzu Yazal Erdem Ankara Şehir Hastanesi, Çocuk Hastanesi, Pediatrik Hematoloji ve Onkoloji Kliniği Ankara, Türkiye arzu.erdem@gmail.com ORCID: 0000-0003-1043-8471

S. Emir 0000-0002-0702-7869 Atılım Üniversitesi Tıp Fakültesi, Pediatrik Hematoloji ve Onkoloji Kliniği Ankara, Türkiye

N. Çakar 0000-0002-1853-0101 Ankara Üniversitesi Tıp Fakültesi, Pediatrik Nefroloji ve Romatoloji Kliniği, Ankara, Türkiye

H.A. Demir 0000-0002-5585-683X Ankara Memorial Hastanesi, Pediatrik Hematoloji ve Onkoloji Kliniği Ankara, Türkiye

D. Özyörük 0000-0002-9615-6522 Ankara Şehir Hastanesi, Çocuk Hastanesi,

Pediatrik Hematoloji ve Onkoloji Kliniği Ankara, Türkiye 


\section{INTRODUCTION}

The five-year survival rates for childhood cancer have approached to nearly $70-80 \%$ due to advances in chemotherapy and supportive care ${ }^{(1,2)}$. Increased survival rates in childhood cancers have led researchers to focus increasingly on long-term treatment-related side effects. It has been shown that long-term survivors of childhood cancer have a higher risk of morbidity and one-third of the survivors report serious or life-threatening complications 30 years after diagnosis of their primary cancer ${ }^{(3,4)}$. Intensive chemotherapy may affect endocrine, cardiac, respiratory, nervous, and renal systems ${ }^{(5)}$. The recent version of Long-Term Follow-Up Guidelines for Survivors of Childhood, Adolescent and Young Adult Cancers recommends screening asymptomatic survivors for the detection of therapy-related late complications and earlier implementation of healthpreserving interventions ${ }^{(6-8)}$.

Since many chemotherapeutic and supportive care drugs are cleared by the kidneys, kidneys are particularly exposed to potential toxic injury. Nephrotoxic drugs such as ifosfamide, methotrexate, cisplatin, carboplatin and antibiotics, radiocontrast agents, abdominal irradiation, nephrectomy, and volume depletion may contribute to the development of renal failure. Data on nephrotoxicity in childhood cancer are rare and relatively small studies are available, in part because of the difficulties in obtaining reliable markers of glomerular and tubular function ${ }^{(8-12)}$.

Glomerular filtration rate has commonly been calculated based on 24-hour creatinine clearance $(\mathrm{ClCr})$ rates which also serve to monitor kidney function. Using creatinine clearance rates to estimate GFR has several limitations, especially in children with chronic medical conditions who are at high risk of kidney dysfunction. The clinical practice guidelines recommend calculating estimated glomerular filtration rate (eGFR) in children with the Schwarz formula, which is based on serum creatinine $(\mathrm{Cr})$ concentration and the height of the child ${ }^{(13-16)}$. For GFR estimation, creatinine and cystatin-C (CysC)based equations have been also established ${ }^{(17-19)}$.
Low-molecular-weight proteins (LMWPs), such as cystatin C, $\beta 2$-microglobulin ( $\beta-2 \mathrm{M}$ ) and microalbumin (Malb) are new markers to monitor subclinical kidney damage ${ }^{(20)}$.

Our aim in this cross-sectional study was to examine renal glomerular and tubular function in a cohort of childhood cancer survivors (CCSs), particularly with solid tumors and lymphomas who had completed their chemotherapy regimens and to determine the incidence and possible risk factors for late-term nephrotoxicity. In addition, we compared the usefulness of calculating estimated GFR (eGFR) based on serum CysC (Cys-eGFR) concentrations, and Schwartz (S-eGFR) formula relative to creatinin clearance in pediatric cancer survivors.

\section{MATERIAL and METHODS}

This cross-sectional study has been performed among CCSs who were in remission and had received nephrotoxic chemotherapy for at least 6 months prior to this chart review, between the years 2004, and 2016. Patients who had received nephrotoxic chemotherapies such as high dose (>1 g/m²/day) methotrexate (HD-MTX) cisplatin (CIS), carboplatin (CARBO), and/or ifosfamide (IFO), and those with primary renal tumors were excluded from the study. The ethics committee of the hospital approved the study protocol.

The information about the gender, age, age at diagnosis of the patients, cancer type and stage, duration of disease, chronic renal diseases, nephrotoxic chemotherapeutic agents used, febrile neutropenia episodes, follow-up time, hypertension, and abdominal radiotherapy was exctracted from the medical files of the patients. Detailed information about physical examination findings, weight, height, pathological findings, and blood pressures was recorded. Blood pressure measurements were carried out for more than two times using sphygmomanometers with appropriate cuff size after the patient rested for 5 minutes. Patients were considered hypertensive if the blood pressure measurements were above the $95^{\text {th }}$ percentile for their sex, age and height according to "The Fourth 
A. Yazal Erdem et al. Examination of Nephrotoxicity in Survivors of Childhood Cancer and Comparison of Methods for Estimating Glomerular Filtration Rate

report on the diagnosis, evaluation, and treatment of high blood pressure in children and adolescents (21)".

The presence of nephrotoxicity was determined by evaluating serum creatinine concentrations, urine dipstick test results, 24-hour urinary creatinine clearance rates, tubular reabsorption of phosphate (TRP), urinary excretion of low molecular weight urinary proteins ( $\beta-2 M$ and Malb), and presence of hypertension.

Estimated GFR was calculated using the Schwartz formula (S-eGFR), and CysC-based equation for estimated glomerular filtration rate (C-eGFR). The precision, and accuracy of the eGFR's were compared with creatinine clearance. Nephrotoxicity was detected in the presence of any of the following findings; hypertension, reduced GFR, and TRP, elevated proteinuria, urinary excretion of $\beta-2 \mathrm{M}$ and Malb in the absence of other causes.

The Schwartz equation was used to estimate GFR as follows: GFR= S-eGFR $\left(\mathrm{mL} / \mathrm{min} / 1.73 \mathrm{~m}^{2}\right)=0.413 \mathrm{x}$ height $(\mathrm{cm}) / \mathrm{PCr}(\mathrm{mg} / \mathrm{dL})(15)$. Serum concentration of CysC was measured, and eGFR was estimated according to the Filler and Lepage formula as follows:

Serum Cys-C: C-eGFR $\left(\mathrm{mL} / \mathrm{min} / 1.73 \mathrm{~m}^{2}\right)=\log G F R=$ $1.962+[1.123 \log (1 / \text { Cys })]^{(17)}$.

Creatinine clearance $(\mathrm{ClCr})$ was calculated using the standard formula: $\mathrm{CrCl}=(\mathrm{UCr} / \mathrm{PCr}) \times(\mathrm{U}$ Volume $/ 1440) \times\left(1.73 / \mathrm{m}^{2}\right)$. (U Cr-urine creatinine, $\mathrm{P}$ Cr-serum creatinine, UVolume-urine volume are measured from 24-hour urine collection samples; plasma and urine creatinine values are expressed in $\mathrm{mg} / \mathrm{dL}$ and body surface area in $\mathrm{m}^{2}$. The constants 1.73 and 1.440 indicate the standardized adult body surface area and the number of minutes in a day, respectively. GFR $<90 \mathrm{ml} / \mathrm{min}$ per $1.73 \mathrm{~m}^{2}$ is considered abnormal according to the Kidney Disease Outcomes Quality Initiative guidelines ${ }^{(13)}$.

Fractional tubular reabsorption of phosphate was calculated using the formula: \%TRP $=100 \times(1$-(UPO4. $\mathrm{PCr}) /(\mathrm{UCr} . \mathrm{PPO} 4)$ ) (UPO4-urine phosphate, and PPO4serum phosphate). Concentrations of serum and urine parameters were measured on an automatic analyzer (Modular PP) using manufacturer's reagents
(Roche Diagnostics, GmbH, Mannheim, Germany). Urine $\beta-2 M$ and Malb were analyzed by the nephelometric method using a BN-ProSpec ${ }^{\circledR}$ device, and serum cystatin (Cys-C) levels were measured by the nephelometric method with SPA Plus analyzer. The presence of proteinuria was defined as urinary protein excretion higher than $4 \mathrm{mg} / \mathrm{m}^{2}$ per hour. The following cut-off values were adopted for

Cys-C (0.56-0.99 mg/L), and Malb-uria (20-200 $\mathrm{mcg} / \mathrm{min}$ ). Urinary $\beta-2 \mathrm{M}$ was defined as "abnormal" in case of an absolute loss of $\geq 0.20 \mathrm{mg} / \mathrm{L}$ or a relative loss of $\geq 0.04 \mathrm{mg} / \mathrm{mmol}$.creatinine.

\section{Statistics}

Statistical analyses were performed using IBM SPSS Statistics V22.0. P value of $\leq 0.05$ was considered as statistically significant. Mean, standard deviation, median, minimum, maximum value frequency, and percentage were used for descriptive statistics. Following verification of biochemical data by ShapiroWilk test, Student's t-test was used for normally, and Mann Whitney U-test was used for abnormally distributed data. Chi-Square test and Fisher's exact test were used for the comparison of qualitative data. Comparison of different methods for estimating GFR were determined by Spearman's correlation coefficient or linear regression analyses.

\section{RESULTS}

The study group comprised 59 childhood cancer survivors including 40 male (68\%) and 19 female (32\%) patients. The mean age of the patients was $10.73 \pm 5.51$ years (range $2.5-23$ ) and the mean followup time after cessation of therapy was $2.67 \pm 2.19$ years (range 0.5-8). Non-Hodgkin lymphomas and brain tumors were the most prevalent group of childhood cancers treated amongst the group. Patient characteristics, and details of chemotherapy are summarized in Table 1. No patient had proteinuria or decreased GFR before chemotherapy at the time of diagnosis. Four patients had recovered from acute kidney injury (AKI) with treatment. Two cases had tumor lysis syndrome at diagnosis, and received dialysis therapy. The other two patients had cisplatin 
related $\mathrm{AKI}$, and was treated with prompt hydration and supportive care. The final GFR values of these four patients were 113, 70,73, and $60 \mathrm{ml} / \mathrm{min} 1,73$ $\mathrm{m}^{2}$. None had hypertension at follow-up.

Table 1. Demographic and treatment characteristics of childhood cancer survivors.

\begin{tabular}{|c|c|}
\hline $\begin{array}{l}\text { Demographic and Clinical } \\
\text { Characteristics }\end{array}$ & Mean $\pm S D$ (range) \\
\hline Gender & $40 \mathrm{M} / 19 \mathrm{~F}$ \\
\hline Age (years) & $10.73 \pm 5.51(2.5-23)$ \\
\hline Age at diagnosis (years) & $7.09 \pm 4.81(0.25-16)$ \\
\hline Follow-up time (years) & $2.67 \pm 2.19(0.5-8)$ \\
\hline Weight $(\mathrm{kg})$ & $35.6 \pm 17.4(13.0-91.2)$ \\
\hline Height (cm) & $135.3 \pm 25.1(90.5-183.0)$ \\
\hline Diagnosis & $(n=59)$ \\
\hline $\mathrm{NHL}$ & 15 \\
\hline Brain tumor & 13 \\
\hline NBL & 10 \\
\hline Germ cell tumor & 8 \\
\hline RMS & 4 \\
\hline Hodgkin & 3 \\
\hline $\mathrm{HBL}$ & 2 \\
\hline Others & 2 \\
\hline Chemotherapy & Cumulative mean $\left(\mathrm{g} / \mathrm{m}^{2}\right)$ (range) \\
\hline HD-MTX (n=15) & $15.48 \pm 7.54(3.0-27.0)$ \\
\hline Cisplatin $(n=36)$ & $0.51 \pm 0.29(0.1-1.64)$ \\
\hline Carboplatin $(n=18)$ & $1.69 \pm 0.85(0.45-2.97)$ \\
\hline Ifosfamid $(n=20)$ & $27.29 \pm 18.45(0.25-54.0)$ \\
\hline Clinical Characteristics & (n) \\
\hline AKI & 4 \\
\hline HT & 2 \\
\hline $\mathrm{FN}$ & 28 \\
\hline Abd RT & 8 \\
\hline
\end{tabular}

NHL: non-Hodgkin Lymphoma, NBL: neuroblastoma, RMS: rhabdomyosarcoma, HBL: hepatoblastoma, ATLS: acute tumor lysis syndrome, AKI: acute kidney injury, HT: hypertension, FN: febrile neutropenia, Abd RT: abdominal radiotherapy, HD-MTX: high dose methotrexate.

Renal dysfunction was detected in 38 out of 59 survivors (64.4\%). The most prevalent manifestation of renal dysfunction was decreased GFR estimated with Schwarz equation ( $\mathrm{n}: 19,32.2 \%)$, followed by increased urinary $\beta 2 \mathrm{M}$ excretion ( $\mathrm{n}: 12,20.4 \%$ ). The other complications in decreasing order of frequency were elevated urine Malb (n:6, 10.1\%), decreased TRP ( $n: 5,8.5 \%)$ and hypertension ( $n: 2,3.4 \%)$. None of the survivors had end-stage renal disease (Table 2). Three survivors had chronic kidney disease, including one patient with eGFR of $38 \mathrm{ml} / \mathrm{min}$ per $1.73 \mathrm{~m}^{2}$, metabolic acidosis, and hypophosphatemia, where the other two survivors were asymptomatic. According to the urine dipstick test, two patients had glucosuria.
Table 2. Renal function parameters.

\begin{tabular}{lc}
\hline Renal Function Tests $(\mathrm{n}: 59)$ & Median (range) \\
\hline eGFR-S $\left(\mathrm{ml} / \mathrm{min} .1 .73 \mathrm{~m}^{2}\right)$ & $103.7(38.1-266.9)$ \\
$30-59\left(\mathrm{ml} / \mathrm{min} .1 .73 \mathrm{~m}^{2}\right) \mathrm{n}: 3$ & $54.9(38.1-57.2)$ \\
$60-89\left(\mathrm{ml} / \mathrm{min} .1 .73 \mathrm{~m}^{2}\right) \mathrm{n}: 16$ & $84.2(60.4-89.9)$ \\
$>90\left(\mathrm{ml} / \mathrm{min} .1 .73 \mathrm{~m}^{2}\right) \mathrm{n}: 40$ & $107.2(90.61-266.9)$ \\
$\mathrm{S} \mathrm{Cr}(\mathrm{mg} / \mathrm{dL})$ & $0.55(0.14-1.24)$ \\
$\mathrm{TRP}(\%)$ & $91.24(42.77-98.98)$ \\
Proteinuria $\left(\mathrm{mg} / \mathrm{m}^{2} / \mathrm{h}\right)$ & $0.41(0.14-3.2)$ \\
U $\beta-2 \mathrm{M}(\mathrm{mg} / \mathrm{L})$ & $0.21(0.08-5.47)$ \\
U microalbumin $(\mathrm{mcg} / \mathrm{min})$ & $4.4(0.72-117.6)$ \\
\hline
\end{tabular}

eGFR-S: estimated glomerular filtration rate according to Schwartz formula, S Cr: serum creatinine, TRP: tubular reabsorption of phosphate, U 6-2M: urinary beta-2 microglobulin.

The cases were evaluated in two groups as those who received high dose MTX $\left(3 \mathrm{~g} / \mathrm{m}^{2}\right)$ and combined chemotherapy. The high dose MTX group was composed of NHL survivors (15 patients), while the combined chemotherapy group consisted of 44 patients with heterogeneous cancers. While various renal complications were observed in $40 \%$ of MTX users $(n=6 / 15)$, this rate was $72.7 \%$ in the non-MTX group $(n=32 / 44)$ ( $p: 0.05)$. Survivors treated with combined chemotherapy had lower TRP and higher proteinuria than those treated with HD-MTX.

Cancer survivors were also evaluated for nephrological complications with respect to febrile neutropenia (FN) ( $\mathrm{n}: 28,47.5 \%)$ episodes and to abdominal radiotherapy $(n=8,13.5 \%)$. Glomerular filtration rate was significantly lower in survivors who had episodes of $\mathrm{FN}$ during their treatment ( $n=28,47.5 \%)$ when compared to those who had not (mean eGFR: $109.5 \pm 39.3 \mathrm{ml} / \mathrm{min}$ per $1.73 \mathrm{~m}^{2}$ and $155 \pm 84.2 \mathrm{ml} / \mathrm{min}$ per $1.73 \mathrm{~m}^{2}$ respectively, $\mathrm{p}=0.01$ ). Sixteen out of 28 survivors with FN episodes had used aminoglycosides as antibiotic treatment. All of the survivors treated with local or whole abdominal irradiation were in the group of combined chemotherapy. Urinary Malb and $\beta-2 \mathrm{M}$ excretion rates were higher in patients that received abdominal irradiation than those didn't. (mean values for urinary Malb: $35.1 \pm 32.6 \mathrm{mcg} / \mathrm{min}$ vs $6.1 \pm 5.8 \mathrm{mcg} /$ $\min , p=0.00$ : mean values for urinary $\beta-2 \mathrm{M}: 1.11 \pm 1.04$ $\mathrm{mg} / \mathrm{L}$ vs $0.56 \pm 0.36 \mathrm{mg} / \mathrm{L}, \mathrm{p}=0.02$ ).

The median S-eGFR and C-eGFR values were 
A. Yazal Erdem et al. Examination of Nephrotoxicity in Survivors of Childhood Cancer and Comparison of Methods for Estimating Glomerular Filtration Rate

Table 3. Demographic, treatment and laboratory characteristics of chemotherapy groups.

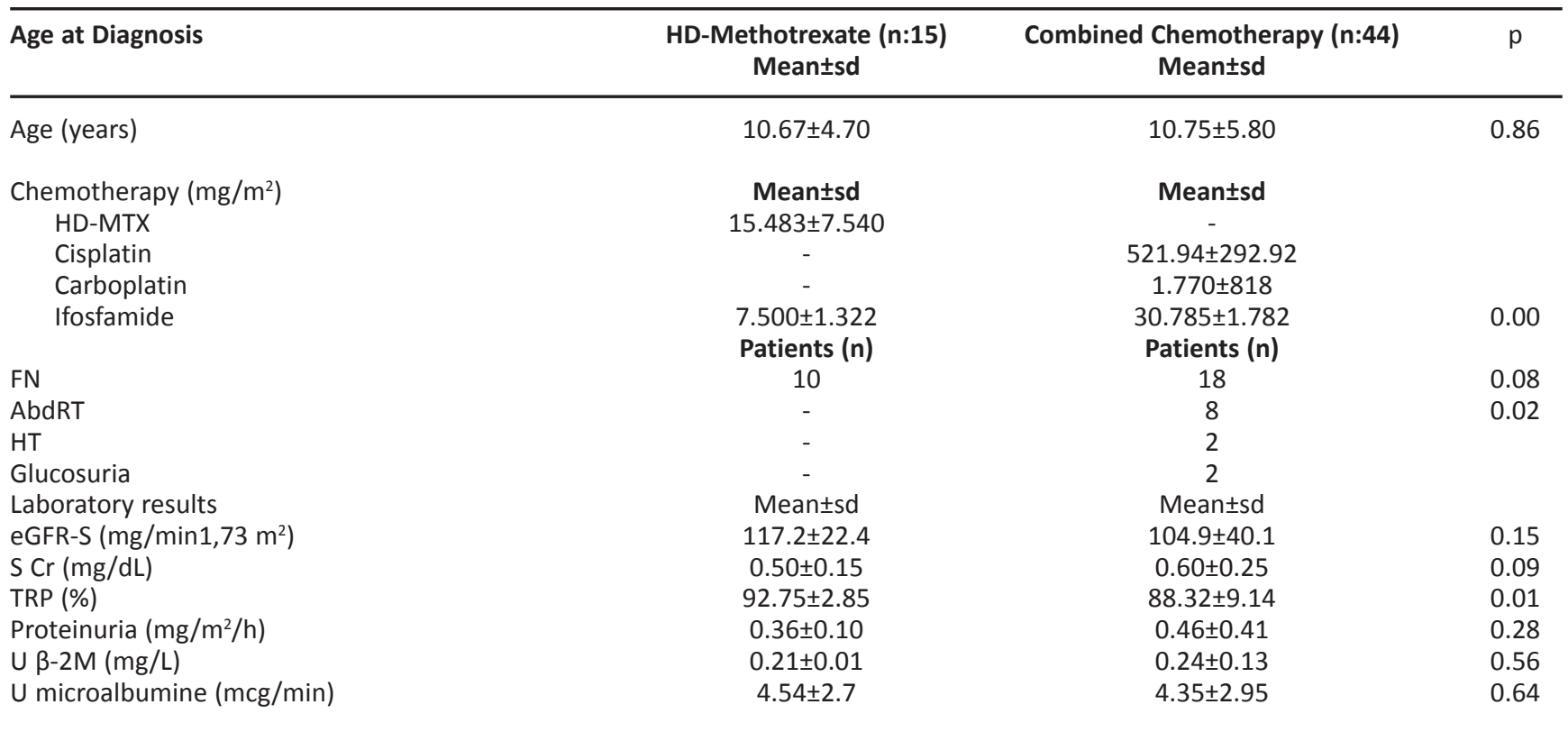

AbdRT: abdominal radiotherapy, eGFR-S: estimated glomerular filtration rate according to Schwartz formula, FN: febrile neutropenia, $S$ Cr: serum creatinine, TRP: tubular reabsorption of phosphate, U 6-2M: urinary beta-2 microglobulin.
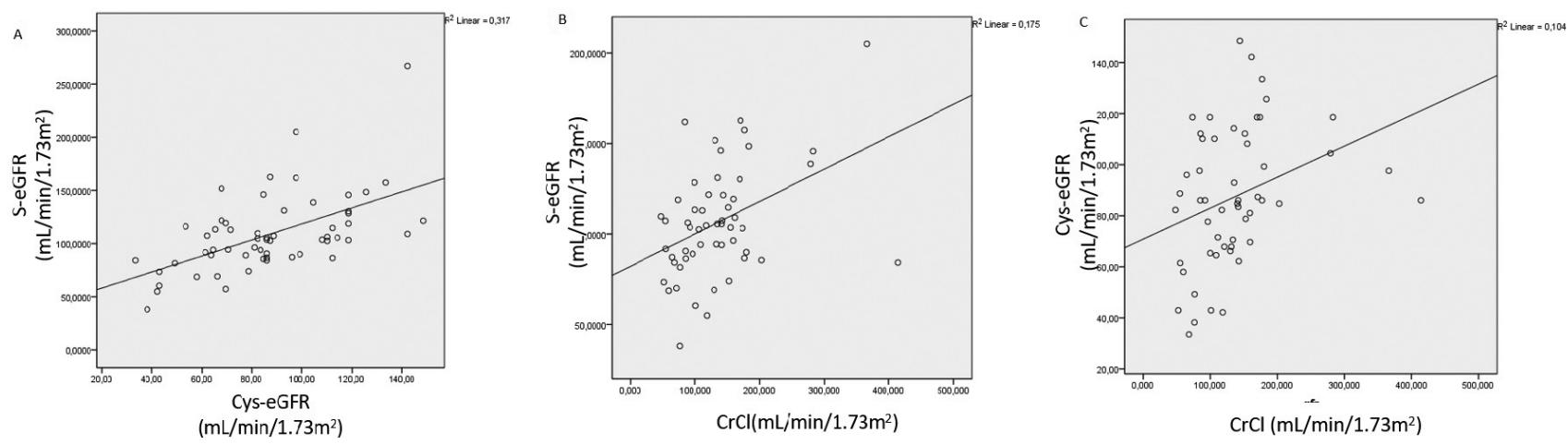

Figure 1. Comparison of creatinine clearance and estimated GFR's revealed positive linear regression lines. A: Correlations between GFR calculated by Cystatin C and estimated GFR with Schwarz formula $(r=0.563, p=0.00)$ B: Correlations between creatinine clearance and GFR calculated with Schwarz formula $(r=+0.418, p=0.02)$. C: Correlations between creatinine clearance and GFR calculated with cystatin C ( $r=0.323, p=0.01)$.

$107.20 \mathrm{~mL} / \mathrm{min} / 1.73 \mathrm{~m}^{2}$, and $86,02 \mathrm{~mL} / \mathrm{min} / 1.73 \mathrm{~m}^{2}$, respectively. Median $\mathrm{CrCl}$ was $130,64 \mathrm{~mL} / \mathrm{min} / 1.73$ $\mathrm{m}^{2}$. When the analysis was made according to the eGFR calculation method used, it was observed that there were moderate correlations between C-eGFR vs S-eGFR ( $r=0.563, p=0.00)$; $\mathrm{CrCl}$ vs S-eGFR ( $r=0.418$, $\mathrm{p}=0.02)$, and $\mathrm{CrCl}$ vs C-eGFR $(r=+0.323, p=0.01)$. Comparisons between e GFR calculation methods are shown in Figure 1.

\section{DISCUSSION}

In this study, renal glomerular and tubular function were investigated in a cohort of childhood cancer survivors who had completed treatment with nephrotoxic chemotherapy. Our results have shown that $65 \%$ of CCSs had at least one marker of renal dysfunction. In the literature, the prevalence of renal complications ranges from $0 \%$ to $84 \%{ }^{(7-11)}$. These varying results may be due to different types of malignancies, treatments received, follow-up times, 
various surveillance tests offered, and definitions of toxicity in studies performed.

In the current study, the most prevalent manifestation of renal dysfunction was decreased GFR, followed by increased $\beta-2 \mathrm{M}$ excretion. In our study, the survivors treated with platinum and ifosfamide-based combined chemotherapy had significantly lower TRP than survivors treated with HD-MTX. It was observed that treatment protocols used in hematologic malignancies had reduced nephrotoxic potential and in these regimens lower cumulative doses of nephrotoxic chemotherapies had been used. In addition, our study showed that, the GFR values in HD-MTX group were preserved, which is compatible with many studies. It has been reported that MTX may cause acute reversible damage but it less frequently leads to renal dysfunction in the long run ${ }^{(5,22-24)}$. It has been reported that combined chemotherapy for ALL is not associated with severe or long-term impairment of renal function ${ }^{(5)}$. In contrast, Grönross et al. (25) showed that HD-MTX treatment significantly decreases GFR and may cause albuminuria in pediatric cancer patients several years after treatment. Wiedeman et al. ${ }^{(26)}$ reassessed the current incidence of HD-MTX-induced renal dysfunction in patients with osteosarcoma, a patient population that is usually treated with HD-MTX, and estimated an incidence rate of $1.8 \%$ for patients with renal dysfunction following treatment with HD-MTX. Stefanowicz et al. (20) reported that solid tumor groups in CCSs had the lowest GFR and higher lowmolecular-weight protein excretion compared with patients with leukemias and/or lymphomas.

We found lower GFRs in 32\% of all survivors. Reduced GFR was more prevalent in survivors who had FN episodes during their treatment. Nephrotoxic antibiotics, including aminoglycosides, vancomycin or amphotericin given during FN episodes could lead to nephrotoxicity. However, there was no significant difference in the GFR results between patients treated with potentially more nephrotoxic chemotherapy drugs, such as cisplatin, ifosfamide, and/or HD-MTX. There are studies demonstrating that cisplatin, ifosfamide chemotherapy, and nephrotoxic antibiotics which were used during FN episodes were associated with lower estimated GFR $(22,27-28)$.

All of the survivors treated with both abdominal irradiation and combined chemotherapy had significantly impaired renal function demonstrated by elevated urinary Malb and $\beta-2 \mathrm{M}$ excretion. Combined chemotherapy and radiotherapy may have contributed to overt renal toxicity. Dekkers et al. ${ }^{(22)}$ reported in a large CCS series with median follow-up time of 18 years that IFO was associated with increased urinary $\beta-2 \mathrm{M}$ excretion. Stefanowicz et al. ${ }^{(20)}$ reported also higher low-molecular-weight protein excretion in solid tumor survivors who were treated with radiotherapy. Other studies have also shown that children receiving higher doses of radiation have a higher risk of renal insufficiency ${ }^{(22,29)}$. In addition, there is a meta-analysis reporting an increased risk of nephrotoxicity after concomitant treatment with aminoglycosides and vancomycin in CCS receiving radiotherapy, but studies yielded conflicting results ${ }^{(27)}$.

In our study, microalbuminuria was detected in $10.1 \%$ of the cases. Other studies have showed similar results; Oberlin et al. ${ }^{(30)}$ detected proteinuria in 24-hour urine samples of $11.3 \%$ of survivors. Kninjenburg et al. ${ }^{(29)}$ reported the presence of albuminuria in $14.5 \%$ of survivors treated with chemotherapy. This complication has been reported to be clinically important in this young population. We found that hypertension was present in only $3.4 \%$ of CCSs, which is relatively low compared with previously reported findings of $15 \%$ and $28 \%$ among CCS ${ }^{(29,31)}$. This discrepancy could be explained by the fact that our survivors were younger children and follow-up time was shorter in the current study.

In our clinical practice, the most frequently available, and easily performed test of renal glomerular function is the estimated GFR calculated with Schwarz formula. Twenty-four-hour urine collection is a challenging procedure in children, therefore $\mathrm{CrCl}$ rest may not be reliable. Creatinine is affected by glomerular filtration and by tubular secretion, thus $\mathrm{CrCl}$ - based GFR can be overestimated by $10-40 \%$ than inulin clearance ${ }^{(32,33)}$. In the present 
A. Yazal Erdem et al. Examination of Nephrotoxicity in Survivors of Childhood Cancer and Comparison of Methods for Estimating Glomerular Filtration Rate

study, $\mathrm{CrCl}$ measurements were higher than S-eGFR, and equations for eGFR demonstrated various differences between S-eGFR and C-eGFR. Some meta-analyses have reported that $\mathrm{Cys} C$ is superior to creatinine as a marker of renal function ${ }^{(34,35)}$. Cystatin $C$ is eliminated mainly by glomerular filtration, correlates with GFR, and it is very sensitive even in mildly impaired kidney function so some studies have suggested it as an ideal GFR marker in pediatric oncology ${ }^{(36)}$. The validation of the Schwartz formula and the calculations based on serum CysC was done in several studies by comparing them to nuclear scanning methods, which suggest that they are closely correlated to GFR ${ }^{(37-39)}$. In our study, we found the strongest correlation between the CysC -GFR and the Schwartz- GFR calculations, and comparison of $\mathrm{CrCl}$ and eGFRs revealed positive linear regression lines, which may be used as alternatives to creatinine-based estimations in CCS.

The major limitation of the study is the low number of heterogeneous patient groups, and its retrospective design. Therefore definitive conclusions could not be drawn regarding the prevalence of renal dysfunction or its risk factors. Future large prospective cohort studies with adequate control groups are needed to clarify the applicability of estimated equations to children and CCSs for late renal toxicity.

In the current study, childhood cancer survivors (CCSs) demonstrated higher rates of renal complications. The significant impairment in glomerular filtration rate and overt renal tubular protein excretion in childhood cancer survivors treated with combined chemotherapies other than HD-MTX, FN episodes, and abdominal radiotherapy were significant parameters for late nephrotoxicity and subclinical renal dysfunction. Early detection of subclinical damage and early intervention may prevent long-term problems that may progress to chronic kidney disease. In addition, according to our results, we can recommend calculation of eGFR using Schwartz formula or Cys-C-based equations, wherever applicable in CCSs who are not able to collect urine 24 hours a day.
Ethics Committee Approval: T.C. Ministry of Health Ankara Pediatrics Hematology Oncology Training and Research Hospital Non-Drug Clinical Research Ethics Committee approval was received (17.10.2012-038). Conflict of Interest: The authors declare no conflict of interest

Funding: No.

Informed Consent: Yes.

\section{REFERENCES}

1. Jemal A, Siegel R, Ward E, Hao Y, Xu J, Murray T, et al. Cancer statistics, 2008. CA Cancer J Clin. 2008;58(2):71-96. https://doi.org/10.3322/CA.2007.0010. Epub 2008 Feb 20.

2. Gatta G, Botta L, Rossi S, Aareleid T, Bielska-Lasota M, Clavel J, et al; EUROCARE Working Group. Childhood cancer survival in Europe 1999-2007: results of EUROCARE-5--a populationbased study. Lancet Oncol. 2014;15(1):35-47.

https://doi.org/10.1016/S1470-2045(13)70548-5. Epub 2013 Dec 5. Erratum in: Lancet Oncol. 2014 Feb;15(2):e52.

3. Oeffinger KC, Mertens AC, Sklar CA, Kawashima T, Hudson MM, Meadows AT, et al. Childhood Cancer Survivor Study. Chronic health conditions in adult survivors of childhood cancer. N Engl J Med. 2006;355(15):1572-82.

https://doi.org/10.1056/NEJMsa060185

4. Bhatia S, Constine LS. Late morbidity after successful treatment of children with cancer. Cancer J. 2009;15(3):174-80. https://doi.org/10.1097/PPO.0b013e3181a58f46

5. Krawczuk-Rybak M, Kuźmicz M, Wysocka J. Renal function during and after treatment for acute lymphoblastic leukemia in children. Pediatr Nephrol. 2005;20(6):782-5. Epub 2005 Mar 22.

https://doi.org/10.1007/s00467-005-1839-3

6. Winn RJ, Botnick WZ. The NCCN Guideline Program: a conceptual framework. Oncology (Williston Park). 1997;11(11A):25-32. PMID: 9430176.

7. Robison LL, Hudson MM. Survivors of childhood and adolescent cancer: life-long risks and responsibilities. Nat Rev Cancer. 2014;14(1):61-70. https://doi.org/10.1038/nrc3634. Epub 2013 Dec 5.

8. Jones DP, Chesney RW. Renal toxicity of cancer chemotherapeutic agents in children: ifosfamide and cisplatin. Curr Opin Pediatr. 1995;7(2):208-13. https://doi.org/10.1097/00008480-199504000-00016

9. Wingard JR, Kubilis P, Lee L, Yee G, White M, Walshe L, et al. Clinical significance of nephrotoxicity in patients treated with amphotericin B for suspected or proven aspergillosis. Clin Infect Dis. 1999;29(6):1402-7. https://doi.org/10.1086/313498

10. Seidel H, Moe PJ, Nygaard R, Nygaard K, Brede W, Borsi JD. Evaluation of serious adverse events in patients treated with protocols including methotrexate infusions. Pediatr Hematol Oncol. 1994;11(2):165-72. https://doi.org/10.3109/08880019409141652

11. Knijnenburg SL, Mulder RL, Schouten-Van Meeteren AY, Bökenkamp A, Blufpand $\mathrm{H}$, van Dulmen-den Broeder $\mathrm{E}$, et al. Early and late renal adverse effects after potentially nephrotoxic treatment for childhood cancer. Cochrane Database Syst Rev. 2013;(10):CD008944. 
https://doi.org/10.1002/14651858.CD008944.pub2

12. Blufpand HN, Hes N, Bökenkamp A, van de Wetering MD, Kaspers GJ. Diversity in renal function monitoring and dose modifications during treatment for childhood cancer: a call for standardization. Pediatr Blood Cancer. 2014;61(2):337-44. https://doi.org/10.1002/pbc.24572

13. National Kidney Foundation. K/DOQI clinical practice guidelines for chronic kidney disease: evaluation, classification, and stratification. Am J Kidney Dis. 2002;39(2 Suppl 1):S1-266.

14. Schwartz GJ, Brion LP, Spitzer A. The use of plasma creatinine concentration for estimating glomerular filtration rate in infants, children, and adolescents. Pediatr Clin North Am. 1987;34(3):571-90. https://doi.org/10.1016/S0031-3955(16)36251-4

15. Schwartz GJ, Muñoz A, Schneider MF, Mak RH, Kaskel F, Warady BA, et al. New equations to estimate GFR in children with CKD. J Am Soc Nephrol. 2009;20(3):629-37. https://doi.org/10.1681/ASN.2008030287

16. Lemley KV. Pediatric nephrology: Estimating GFR in children: Schwartz redux. Nat Rev Nephrol. 2009;5(6):310-1. https://doi.org/10.1038/nrneph.2009.56

17. Filler $\mathrm{G}$, Lepage $\mathrm{N}$. Should the Schwartz formula for estimation of GFR be replaced by cystatin C formula? Pediatr Nephrol. 2003;18(10):981-5. https://doi.org/10.1007/s00467-003-1271-5

18. Kazama JJ, Kutsuwada K, Ataka K, Maruyama H, Gejyo F. Serum cystatin $C$ reliably detects renal dysfunction in patients with various renal diseases. Nephron. 2002;91(1):13-20. https://doi.org/10.1159/000057599

19. Laterza OF, Price CP, Scott MG. Cystatin C: an improved estimator of glomerular filtration rate? Clin Chem. 2002;48(5):699-707. https://doi.org/10.1093/clinchem/48.5.699

20. Stefanowicz J, Owczuk R, Aleksandrowicz E, Owczarzak A, Kurylak A, Adamkiewicz-Drożyńska $E$, et al. Renal function and low-molecular-weight proteins (cystatin C, ß2-microglobulin, neutrophil gelatinase-associated lipocalin) in child and young adult cancer survivors. J Pediatr Hematol Oncol. 2012;34(6):461-6. https://doi.org/10.1097/MPH.0b013e318257fd89

21. National High Blood Pressure Education Program Working Group on High Blood Pressure in Children and Adolescents. The fourth report on the diagnosis, evaluation, and treatment of high blood pressure in children and adolescents. Pediatrics. 2004;114(2 Suppl $4^{\text {th }}$ Report):555-76. https://doi.org/10.1542/peds.114.2.S2.555

22. Dekkers IA, Blijdorp K, Cransberg K, Pluijm SM, Pieters R, Neggers SJ, et al. Long-term nephrotoxicity in adult survivors of childhood cancer. Clin J Am Soc Nephrol. 2013;8(6):922-9. https://doi.org/10.2215/CJN.09980912

23. Kaya Z, Gursel T, Bakkaloglu SA, Kocak U, Atasever T, Oktar SO. Evaluation of renal function in Turkish children receiving BFM-95 therapy for acute lymphoblastic leukemia. Pediatr Hematol Oncol. 2007;24(4):257-67. https://doi.org/10.1080/08880010701441286

24. Hempel L, Misselwitz J, Fleck C, Kentouche K, Leder C, Appenroth D, et al. Influence of high-dose methotrexate therapy (HD-MTX) on glomerular and tubular kidney function. Med Pediatr Oncol. 2003;40(6):348-54.

https://doi.org/10.1002/mpo.10293

25. Grönroos $\mathrm{MH}$, Jahnukainen T, Möttönen $\mathrm{M}$, Perkkiö $\mathrm{M}$, Irjala $\mathrm{K}$, Salmi TT. Long-term follow-up of renal function after highdose methotrexate treatment in children. Pediatr Blood
Cancer. 2008;51(4):535-9.

https://doi.org/10.1002/pbc.21650

26. Widemann BC, Adamson PC. Understanding and managing methotrexate nephrotoxicity. Oncologist. 2006;11(6):694703. Review. https://doi.org/10.1634/theoncologist.11-6-694

27. Kooijmans EC, Bökenkamp A, Tjahjadi NS, Tettero JM, van Dulmen-den Broeder E, van der Pal HJ, et al. Early and late adverse renal effects after potentially nephrotoxic treatment for childhood cancer. Cochrane Database Syst Rev. 2019;3(3):CD008944.

https://doi.org/10.1002/14651858.CD008944.pub3. PMID: 30855726; PMCID: PMC6410614.

28. Barnett LMA, Cummings BS. Nephrotoxicity and Renal Pathophysiology: A Contemporary Perspective. Toxicol Sci. 2018;164(2):379-390. https://doi.org/10.1093/toxsci/kfy159. PMID: 29939355.

29. Knijnenburg SL, Jaspers MW, van der Pal HJ, Schouten-van Meeteren AY, Bouts AH, Lieverst JA, et al. Renal dysfunction and elevated blood pressure in long-term childhood cancer survivors. Clin J Am Soc Nephrol. 2012;7(9):1416-27. https://doi.org/10.2215/CJN.09620911

30. Oberlin O, Fawaz O, Rey A, Niaudet P, Ridola V, Orbach D, et al. Long-term evaluation of Ifosfamide-related nephrotoxicity in children. J Clin Oncol. 2009;27(32):5350-5. https://doi.org/10.1200/JCO.2008.17.5257

31. Haddy TB, Mosher RB, Reaman GH. Hypertension and prehypertension in long-term survivors of childhood and adolescent cancer. Pediatr Blood Cancer. 2007;49(1):79-83. https://doi.org/10.1002/pbc.20886

32. Filler G, Priem F, Vollmer I, Gellermann J, Jung K. Diagnostic sensitivity of serum cystatin for impaired glomerular filtration rate. Pediatr Nephrol. 1999;13(6):501-5. https://doi.org/10.1007/s004670050646

33. Stickle D, Cole B, Hock K, Hruska KA, Scott MG. Correlation of plasma concentrations of cystatin $\mathrm{C}$ and creatinine to inulin clearance in a pediatric population. Clin Chem. 1998;44(6 Pt 1):1334-8. https://doi.org/10.1093/clinchem/44.6.1334

34. Stefanowicz J, Kosiak M, Romanowicz G, Owczuk R, Adamkiewicz-Drożyńska E, Balcerska A. Glomerular filtration rate and prevalence of chronic kidney disease in Wilms' tumour survivors. Pediatr Nephrol. 2011;26(5):759-66. https://doi.org/10.1007/s00467-011-1759-3

35. Dharnidharka VR, Kwon C, Stevens G. Serum cystatin C is superior to serum creatinine as a marker of kidney function: a meta-analysis. Am J Kidney Dis. 2002;40(2):221-6. https://doi.org/10.1053/ajkd.2002.34487

36. Rechenauer T, Zierk J, Gräfe D, Rascher W, Rauh M, Metzler M. A Comparison of GFR Estimation Formulae in Pediatric Oncology. Klin Padiatr. 2018;230(3):142-50. English. https://doi.org/10.1055/a-0587-5753

37. Levey AS, Coresh J, Tighiouart H, Greene T, Inker LA. Measured and estimated glomerular filtration rate: current status and future directions. Nat Rev Nephrol. 2020;16(1):51-64. https://doi.org/10.1038/s41581-019-0191-y

38. Llanos-Paez CC, Staatz C, Lawson R, Hennig S. Comparison of methods to estimate glomerular filtration rate in paediatric oncology patients. J Paediatr Child Health. 2018;54(2):141-7. https://doi.org/10.1111/jpc.13752

39. Pottel H, Mottaghy FM, Zaman Z, Martens F. On the relationship between glomerular filtration rate and serum creatinine in children. Pediatr Nephrol. 2010;25(5):927-34. https://doi.org/10.1007/s00467-009-1389-1 